\title{
Desert Research and Technology Study 2003 Trip Report/ICES Paper
}

\author{
Amy Ross, Joseph J. Kosmo, Barbara Janoiko NASA-Johnson
}

Space Center, Dean Eppler PhD, SAIC

\section{INTRODUCTION}

The Advanced Extra-vehicular Activity (EVA) team of the National Aeronautics and Space Administration (NASA) Johnson Space Center (JSC) Crew and Thermal Systems Division (CTSD) participated in the Desert Research and Technology Study (RATS) in September 2003, at Meteor Crater, AZ. The Desert RATS is an integrated remote field site test with team members from several NASA centers (Johnson Space Center; Glenn and Ames Research Centers) and universities (Bowling Green State University, University of Cincinnati, Massachusetts Institute of Technology) participating. Each week of the two-week field test had a primary focus. The primary test hardware for the first week was the 1-Gravity Lunar Rover Training Vehicle, or Grover, which was on loan to NASA from the United States Geological Survey (USGS) Astrogeology Research Program. The 2003 Grover driving test results serve as a rover performance characterization baseline for the Science, Crew, Operations and Utility Testbed (SCOUT) project team, which will be designing and fabricating a next generation roving vehicle prototype in Fiscal Year (FY) 2004. The second week of testing focused on EVA geologic traverses that utilized a geologic sample field analysis science trailer and also focused on human-robotic interaction between the suited subjects and the EVA Robotic Assistant (ERA). This paper will review the Advanced EVA team's role in the context of the overall Desert RATS, as well as the EVA team results and lessons learned. For information regarding other test participants' results, the authors can refer interested parties to the test reports produced by those Desert RATS teams. 
Desert Research and Technology Study 2003 Trip Report/ICES Paper

Amy Ross, Joseph J. Kosmo, Barbara Janoiko NASA-Johnson

Space Center, Dean Eppler PhD, SAIC

\section{INTRODUCTION}

The Advanced Extra-vehicular Activity (EVA) team of the National Aeronautics and Space Administration (NASA) Johnson Space Center (JSC) Crew and Thermal Systems Division (CTSD) participated in the Desert Research and Technology Study (RATS) in September 2003, at Meteor Crater, AZ. The Desert RATS is an integrated remote field site test with team members from several NASA centers (Johnson Space Center; Glenn and Ames Research Centers) and universities (Bowling Green State University, University of Cincinnati, Massachusetts Institute of Technology) participating. Each week of the two-week field test had a primary focus. The primary test hardware for the first week was the 1-Gravity Lunar Rover Training Vehicle, or Grover, which was on loan to NASA from the United States Geological Survey (USGS) Astrogeology Research Program. The 2003 Grover driving test results serve as a rover performance characterization baseline for the Science, Crew, Operations and Utility Testbed (SCOUT) project team, which will be designing and fabricating a next generation roving vehicle prototype in Fiscal Year (FY) 2004. The second week of testing focused on EVA geologic traverses that utilized a geologic sample field analysis science trailer and also focused on human-robotic interaction between the suited subjects and the EVA Robotic Assistant (ERA). This paper will review the Advanced EVA team's role in the context of the overall Desert RATS, as well as the EVA team results and lessons learned. For information regarding other test participants' results, the authors can refer interested parties to the test reports produced by those Desert RATS teams.

\section{BACKGROUND}

The 2003 RATS was the fifth remote field site test in which the Advanced EVA team has participated. This year's test was the most complex and ambitious field test to date and builds upon previous field trips that each had increasingly integrated objectives. The field trips are briefly described in the following table to illustrate this progression.

Table 1: Progression of Remote Field Site Tests

\begin{tabular}{|c|c|l|l|}
\hline Year & Location & \multicolumn{1}{|c|}{ Test Description } & \multicolumn{1}{c|}{ Major Participants } \\
\hline 1998 & Flagstaff, AZ & $\begin{array}{l}\text { Compared unsuited and suited } \\
\text { geologic task performance }\end{array}$ & $\begin{array}{l}\text {-JSC Advanced EVA team } \\
\text {-JSC Anthropometrics and } \\
\end{array}$ \\
& $\begin{array}{l}\text { (Cinder Lake, } \\
\text { Grand Falls, }\end{array}$ & & Biomechanics Facility \\
& $\begin{array}{l}\text { SP Mountain, } \\
\text { Meteor Crater- } \\
\text { southwest side } \\
\text { of crater) }\end{array}$ & & \\
\hline
\end{tabular}




\begin{tabular}{|c|c|c|c|}
\hline 1999 & $\begin{array}{l}\text { Silver Lake, } \\
\text { CA }\end{array}$ & $\begin{array}{l}\text { Astronaut-Rover (ASRO) } \\
\text { Interaction Test: ASRO was the } \\
\text { first suited subject-robot } \\
\text { interaction test for planetary } \\
\text { exploration operations. ASRO } \\
\text { studied human-robotic interaction } \\
\text { and the division of labor between } \\
\text { human and robot helpful in } \\
\text { performing EVA geologic surface } \\
\text { exploration. The Marsakhod } \\
\text { robot was provided by the Ames } \\
\text { Research Center. Deployment of } \\
\text { a mock-up Mars Scientific } \\
\text { Experiment Package (Mars SEP) } \\
\text { was also performed. }\end{array}$ & $\begin{array}{l}\text {-JSC Advanced EVA team } \\
\text {-Ames Research Center } \\
\text { (ARC) Marsakhod team }\end{array}$ \\
\hline 2000 & $\begin{array}{c}\text { Flagstaff, AZ } \\
\text { (Cinder Lake, } \\
\text { SP Mountain, } \\
\text { Meteor Crater- } \\
\text { southwest side } \\
\text { of crater) }\end{array}$ & $\begin{array}{l}\text { Testing concentrated on EVA } \\
\text { geologic traverses, deployment of } \\
\text { surface power systems (e.g. solar } \\
\text { panels and power cables), and } \\
\text { core sample drilling using a drill } \\
\text { rig. This test continued the study } \\
\text { of human-robotic interaction with } \\
\text { the JSC EVA Robotic Assistant } \\
\text { (ERA). The ERA aided the suited } \\
\text { subject with the above tasks by } \\
\text { carrying the geology tools and } \\
\text { pulling the power system } \\
\text { deployment trailer. }\end{array}$ & $\begin{array}{l}\text { - ISC Advanced EVA team } \\
\text {-JSC ERA team }\end{array}$ \\
\hline 2002 & $\begin{array}{c}\text { Flagstaff, AZ } \\
\text { (Joseph City, } \\
\text { Meteor Crater- } \\
\text { Bar-T-Bar } \\
\text { Ranch and } \\
\text { southwest side } \\
\text { of crater) }\end{array}$ & $\begin{array}{l}\text { The sophistication of the EVA } \\
\text { traverses and human-robotic } \\
\text { interaction was increased via the } \\
\text { addition of the in-field geological } \\
\text { sample analysis science trailer } \\
\text { and the EVA Informatics pack, or } \\
\text { Info-pak, respectively. } \\
\text { Additionally, a satellite link for } \\
\text { video, voice, and data was } \\
\text { provided from the field test to the } \\
\text { Exploration Planning and } \\
\text { Operations Center (ExPOC) by } \\
\text { the GRC communications team. }\end{array}$ & $\begin{array}{l}\text {-JSC Advanced EVA team } \\
\text {-JSC ERA team } \\
\text { - JSC Exploration Planning } \\
\text { and Operations Center } \\
\text { (ExPOC) } \\
\text { - Glenn Research Center } \\
\text { (GRC) Communication } \\
\text { Team } \\
\text { - ARC Mobile Agents team } \\
\text { - University researchers }\end{array}$ \\
\hline 2003 & $\begin{array}{l}\text { Flagstaff, AZ } \\
\text { (Meteor } \\
\text { Crater-Bar-T- } \\
\text { Bar Ranch and }\end{array}$ & $\begin{array}{l}\text { Desert RATS 2003: The first } \\
\text { week was dedicated to the 1-G } \\
\text { Lunar Rover Training Vehicle } \\
\text { driving tests, both suited and } \\
\text { unsuited. The second week }\end{array}$ & $\begin{array}{l}\text {-JSC Advanced EVA team } \\
\text {-JSC ERA team } \\
\text { - JSC SCOUT team } \\
\text { (consists of members from } \\
\text { seven JSC Engineering }\end{array}$ \\
\hline
\end{tabular}




\begin{tabular}{|c|c|c|}
\hline $\begin{array}{l}\text { southwest side } \\
\text { of crater. See } \\
\text { Figure } 1 \text { for } \\
\text { test site } \\
\text { locations.) }\end{array}$ & $\begin{array}{l}\text { concentrated on performing } \\
\text { geological EVA traverses } \\
\text { utilizing a second-generation } \\
\text { science trailer and Informatics } \\
\text { pack. The communication } \\
\text { infrastructure provided by GRC } \\
\text { and ExPOC participation was } \\
\text { expanded. }\end{array}$ & $\begin{array}{l}\text { Directorate divisions) } \\
\text { - JSC Exploration Planning } \\
\text { and Operations Center } \\
\text { (ExPOC) } \\
\text {-Glenn Research Center } \\
\text { (GRC) Communication } \\
\text { Team } \\
\text {-University researchers }\end{array}$ \\
\hline
\end{tabular}

From Table 1, it can be seen that the Advanced EVA team has performed all but one of its field tests in the Flagstaff, AZ area. The Flagstaff Field Center of the United States Geological Survey (USGS) is home to the Astrogeology Research Program. Several sites around Flagstaff, AZ analogous to the Lunar and Martian surfaces have been identified and are utilized by the Advanced EVA team. Additionally, the field test teams use the USGS facility to stage test supplies and to work on test hardware. In return, the Advanced EVA team aids in remote-sensing data ground truth studies for the USGS. This cooperation is enabled by a Memorandum of Understanding between NASA JSC and the USGS for support of the field tests.

\section{DESERT RATS 2003 TEST DESCRIPTION}

The two-week Desert RATS consisted of two primary tests. During the first week of RATS 2003, the Advanced EVA team supported the SCOUT team's Grover testing. The second week was dedicated to EVA traverse and human-robotic interaction tests. The overall schedule of activities that were performed is given in Table 2. The test hardware, test objectives, testing accomplished, and results and lessons learned from each week are discussed below. Additionally, significant general test results and lessons learned are also discussed.

Table 2: Desert RATS 2003 Test Activities

\begin{tabular}{|c|c|c|c|c|c|c|}
\hline & & & & & & $\begin{array}{l}8 / 30 / 03 \\
\text {-Travel to } \\
\text { Flagstaff }\end{array}$ \\
\hline $\begin{array}{l}8 / 31 \\
\text {-Travel } \\
\text { to and } \\
\text { arrive } \\
\text { Flagstaff }\end{array}$ & $\begin{array}{l}\text { 9/1 } \\
\text {-Test } \\
\text { hardware } \\
\text { checkout } \\
\text {-Bar-T- } \\
\text { Bar } \\
\text { Ranch } \\
\text { field test } \\
\text { site } \\
\text { inspection }\end{array}$ & $\begin{array}{l}9 / 2 \\
\text {-Two } \\
\text { shirtsleeve } \\
\text { Grover } \\
\text { dry runs, } \\
\text { one with } \\
\text { each test } \\
\text { subject }\end{array}$ & $\begin{array}{l}\text { 9/3 } \\
\text {-ExPOC } \\
\text { briefing } \\
\text {-Suited } \\
\text { Grover run } \\
\text { with Mark } \\
\text { III } \\
\text {-Nighttime } \\
\text { Grover } \\
\text { lights }\end{array}$ & $\begin{array}{l}\mathbf{9 / 4} \\
\text {-Suited } \\
\text { Grover } \\
\text { run with I- } \\
\text { Suit }\end{array}$ & $\begin{array}{l}\text { 9/5 } \\
\text {-Return } \\
\begin{array}{l}\text { Grover to } \\
\text { museum } \\
\text { configuration }\end{array} \\
\text {-C-AT } \\
\text { comm. } \\
\text { system } \\
\text { trouble- } \\
\text { shooting }\end{array}$ & $\begin{array}{l}\mathbf{9 / 6} \\
\text {-Stage } \\
\text { teams for } \\
\text { week } 2 \\
\text { testing on } \\
\text { southwest } \\
\text { side of } \\
\text { crater }\end{array}$ \\
\hline
\end{tabular}




\begin{tabular}{|c|c|c|c|c|c|c|}
\hline & & & $\begin{array}{l}\text { illumination } \\
\text { study }\end{array}$ & & $\begin{array}{l}\text {-Southwest } \\
\text { side of crater } \\
\text { field test site } \\
\text { inspection }\end{array}$ & \\
\hline $\begin{array}{l}9 / 7 \\
\text {-Day off }\end{array}$ & $\begin{array}{l}\mathbf{9 / 8} \\
\text {-Return } \\
\text { Grover to } \\
\text { USGS } \\
\text { display } \\
\text {-Set up } \\
\text { two EVA } \\
\text { traverse } \\
\text { paths-1) } \\
\text { science } \\
\text { trailer } \\
\text { path and } \\
\text { 2) } \\
\text { nighttime } \\
\text { path }\end{array}$ & $\begin{array}{l}9 / 9 \\
\text {-Bad } \\
\text { weather at } \\
\text { test site } \\
\text { cancelled } \\
\text { day's } \\
\text { activities }\end{array}$ & $\begin{array}{l}\mathbf{9 / 1 0} \\
\text {-EVA } \\
\text { traverse } \\
\text { with I-Suit } \\
\text {-Info-pak } \\
\text { test } \\
\text {-Night } \\
\text { EVA } \\
\text { traverse } \\
\text { with Mark } \\
\text { III } \\
\text {-ExPOC } \\
\text { interaction }\end{array}$ & $\begin{array}{l}\text { 9/11 } \\
\text {-EVA } \\
\text { traverse } \\
\text { with Mark } \\
\text { III } \\
\text {-ExPOC } \\
\text { interaction }\end{array}$ & $\begin{array}{l}\text { 9/12 } \\
\text {-Public } \\
\text { outreach } \\
\text { event at } \\
\text { Meteor } \\
\text { Crater } \\
\text {-Final } \\
\text { packing for } \\
\text { return trip }\end{array}$ & $\begin{array}{l}\mathbf{9 / 1 3} \\
\text {-Travel to } \\
\text { Houston }\end{array}$ \\
\hline $\begin{array}{l}\mathbf{9 / 1 4} \\
\text {-Travel } \\
\text { to and } \\
\text { arrive in } \\
\text { Houston }\end{array}$ & & & & & & \\
\hline
\end{tabular}

\section{Advanced EVA Team Desert RATS 2003 Test Hardware Description}

The Advanced EVA team provided the following major test hardware for Desert RATS 2003:

\section{Mark III Space Suit Technology Demonstrator}

The Mark III was one of two advanced configuration space suits used in the field test (See Figure 2). Design of the Mark III enables partial gravity walking, and it represents a hybrid space suit configuration in that it is composed of hard elements such as a hard upper torso and brief, and of soft components such as fabric elbows and knees. The planetary mobility of the suit is primarily achieved by its use of bearings in multi-axis mobility joint systems. The Mark III, in addition to bearings at the shoulder and upper arm, has bearings at the waist, upper hip, mid-hip, upper leg ( 3 bearing hip), and ankle joints. The suit is entered through a hatch on the backside of the hard upper torso (rearentry suit). Suit subjects are interfaced to the suit structure by means of a waist belt weight relief system and shoulder straps. The boots of the Mark III are designed for walking traverses over rough terrain. The boots were derived from a military jump-style boot and incorporate a patterned gore, single-axis ankle joint. The Mark III suit (less 
cryo-backpack) weighs approximately $54.54 \mathrm{~kg}(120 \mathrm{lbs})$ and was pressurized to 193.9 torr (3.75 pounds per square inch) for this test series.

\section{I-Suit}

The I-Suit is the other advanced configuration space suit that was used in Desert RATS 2003 (See Figure 3). The I-Suit also is designed to be a partial gravity walking suit. However, in contrast to the Mark III, the I-Suit utilizes a soft upper torso and soft hip and brief elements. The I-Suit incorporates a limited number of bearings with bearings located at the shoulder, upper arm, upper hip, and upper leg ( 2 bearing hip) joints. The boots of the I-Suit consists of the lower portion of an off-the-shelf work boot and a patterned convolute ankle joint. The size 11 boot also incorporates air bladders that can be inflated with a pump to anchor various sized feet in the boot. The suit has a horizontal body seal closure and a rigid frame for backpack integration. The I-Suit weighs $29.03 \mathrm{~kg}$ (64 lbs) and was pressurized to 193.9 torr (3.75 pounds per square inch) for this test series.

\section{Liquid Air Backpack System}

The Liquid Air Backpack (LAB) stores fourteen pounds of liquid air in an on-back dewar. The LAB provides the following functions: breathing air to the suited subject, suit pressurization, carbon dioxide removal from the ventilation loop, and heat exchange for the liquid cooling garment. The LAB is attached to the rear of the upper torso of the space suits and weighs $38.1 \mathrm{~kg}$ (84 lbs).

Test support equipment for the $\mathrm{LAB}$ includes the recharge system and the liquid air storage dewar. The recharge system is used to liquefy certified pressurized breathing air. Certified breathing air from ' $\mathrm{K}$ '-bottles flows through a heat exchanger in the recharge system. The recharge station heat exchanger is submerged in a bath of liquid nitrogen, which liquefies the air. The liquid air can then be used to charge the LAB directly. However, for field tests, the liquid air is stored in the storage dewar. The LAB is then charged at the test site from the storage dewar.

\section{In-Field Geological Sample Analysis Science Trailer}

The science trailer, shown in Figure 2, is the second-generation science trailer. The first use of a science trailer was during the 2002 field test. The 2003 trailer was built on lessons learned from the 2002 test activities. The purpose of the science trailer is to provide an in-field geological sample analysis capability. This allows the planetary surface exploration crewmember to be more discerning in their selection of samples for return to the habitat for further analysis. Geological sample collection tools and analysis instruments aboard the science trailer include: EVA geology tool pallet, field notebook computer, digital camera with imaging software, ultraviolet light, digital microscope, infrared camera, and WS-1 rock crusher (see Figure 4). The science trailer can be pulled, either by the EVA Robotic Assistant (ERA) or, by the 6-wheel All-Terrain Vehicle (ATV). 
Wireless Voice Communication System

The Advanced EVA team's communication system is used to provide full-duplex, wireless voice communication between the test subject and the test team. The system consists of a transmitting-receiving base station, the base station antenna, five test team belt-packs, and one space suit belt pack. The space suit belt pack has been modified to remove the side tone to limit feedback to the space suit microphones. The communication system operates in the $2.4 \mathrm{GHz}$ band.

Suit Donning Trailer

The suit donning trailer carries the test support equipment required to support pressurized space suit tests in the field. The test support equipment includes the communication system, the liquid air storage dewar, the suit storage box, and the suit donning stand.

6-Wheel All-Terrain Vehicle (ATV)

The 6-wheel ATV is a small, two-seat, gasoline-engine vehicle used in the field to haul the suit donning trailer and the science trailer. It also ferries equipment and personnel as required.

\section{Logistics Trailer}

The logistics trailer is a $7.32 \mathrm{~m}(24 \mathrm{ft})$ long trailer in which the above hardware is stored and transported. Additional test support equipment, such as toolboxes, shade canopies, tables, spare liquid cooling garments, etc., is also stored in the logistics trailer. The Advanced EVA team rents a 1-ton, 350 horsepower diesel truck to haul the trailer.

\section{Desert RATS 2003 Test Objectives, Testing Performed and Results \\ Week 1-1-G Lunar Rover Training Vehicle (Grover) Test Objectives and Testing Performed}

The first week of testing focused on driving tests with the USGS Grover vehicle to obtain baseline rover performance characterization.

The Grover is one example of the long history of cooperation between the USGS and NASA. The United States Geological Survey built the 1-G Lunar Rover Trainer, or Grover, in the late 1960's to train the Apollo 15, 16, and 17 crews for driving the Lunar Rover on the lunar surface. Since that time, the Grover had dwelt in museums.

However, in 2000 the Advanced EVA team initiated arrangements to borrow the Grover for roving EVA traverse tests. Then, at the inception of the SCOUT project in FY2003, the SCOUT team requested use of the Grover to serve as a baseline for rover performance characterization and as a test bed for rover sub-system technologies, such as the In-situ Hydrogen-Oxygen Power Plant (IHOPP) fuel cell and an Embedded Global Positioning System (GPS) Inertial navigation system (EGI). The Grover was transferred to the Johnson Space Center in March of 2003 for refurbishment and outfitting with SCOUT test hardware. The SCOUT team transported the modified Grover back to Flagstaff for the 2003 Desert RATS. 
The Advanced EVA team served in a support role to the SCOUT team during the first week of testing by providing two test subjects who drove the Grover over a pre-defined traverse path at the Bar-T-Bar ranch test site in both shirtsleeve and space suited conditions. A total of four driving tests were supported by the advanced EVA team (see Table 2: Desert RATS 2003 Test Activities). Each test subject performed one shirtsleeve driving test, and then each subject performed a suited driving test with one subject wearing the Mark III suit and the other subject in the I-Suit. The driving test traverse path and field test site 1 is shown in Figure 5. The subject stopped, egressed the vehicle, performed a geologic task, and ingressed the vehicle at each waypoint along the traverse.

In addition to the four driving tests, a nighttime illumination study with the SCOUT Light-Emitting Diode (LED) light array was performed. A white, life-sized, foam-core cut-out of a space suited figure was used to assess the distance at which moving and stationary objects were visible to the human eye and to camera views. This test also provided data on the illumination given by the LED array at various distances from the Grover. During this test, the Grover was stationary and only the space suit cut-out was moved by test personnel.

The Transportable Earth Station satellite communication system experienced difficulties during the first week of field testing, so ExPOC interactions could not be conducted.

\section{Week 1 -1-G Lunar Rover Training Vehicle (Grover) Test Results}

The subjective comments regarding ergonomics information for rover 'cockpit' design generated during the space suited driving tests were of principle interest to the Advanced EVA team. The test subjects focused on two primary issues. The first was the Grover controller performance. Subjects noted slop and lag in the steering that made it difficult to anticipate and maintain required control inputs. Compounding this was the lack of an arm or hand rest on the rover to help stabilize the subject's arm; therefore they were unable to produce consistent or controlled steering and speed inputs. Unintentional control inputs were made as the hand was bounced around while driving over rocks and uneven terrain. Subjects also reported difficulty in maintaining a steady speed, as the throttle itself was not very responsive. Finally, the subjects noted that it was difficult to discern whether the throttle was in the low or high-speed mode. The feedback from the controller to the subject, in this regard, was poor.

The second issue regarded seat/cockpit ergonomics. As mentioned above, the subjects noted the need for a method of stabilizing their arm/hand while driving. In association with hand/arm stabilization, the subjects expressed the desire for a seat belt. Although the subjects never felt in imminent danger of falling out of the rover, it was necessary to exert significant effort and force against the foot bar to maintain a stable body position in the seat. These performance comments will be taken into consideration by the SCOUT team in the SCOUT vehicle design.

In addition to lessons learned during nominal test operations, the team learned from offnominal situations. For example, the Grover battery died during the Mark III driving test on Wednesday, September 3rd. The suited subject had to walk back from where the 
Grover stopped to the suit donning trailer. The walk back traverse was 218 meters (708 feet). This provided a good data point on traverse length and walk-back capability. Moreover, the EVA team encountered equipment problems not previously experienced. On Thursday, September 4th, while charging the LAB for the I-Suit Grover driving test, the vent/build-up valve froze open and could not be turned to build-up. The test team used a hot air gun to defrost the valve enough to be able to close it. This was the first time in the operational history of the LAB that this anomaly had occurred. Following the test, the team inspected the valve and could discern no structural or mechanical abnormality.

Lastly, Figure 6 illustrates the results from the SCOUT LED light bar night illumination test. In order from least to greatest visual capability, the space suited figure cut-out could be discerned at 50 meters in the video camera, with the unaided eye at 150 meters when the cut-out was stationary, and at 207 meters when the cut-out was in motion. The ability to discern the stationary cut-out coincided with the limit of the LED beam at 150 meters. The half moon provided 0.2-0.5 LUX of illumination on the night of the test. Figure 7 shows the Grover during the night illumination test.

\section{Week 2 - EVA Traverses: Science Trailer and Nighttime Test Objectives and Testing Performed}

The focus of the second week of RATS activities was EVA geologic traverses. Figure 7 illustrates the two separate traverse paths that were utilized. The straight path was used for the science trailer/human-robot interaction traverses, and the oval traverse path was walked during the night traverse. For the science trailer traverses, either the ERA or the ATV pulled the science trailer. The test subject then followed the procedures for collecting and analyzing geologic samples at the selected waypoints along the traverse path. Data from the science trailer instruments and the ERA were sent to the ExPOC, an exploration mission control center testbed, via the GRC Transportable Earth Station and Mobile Communcations Facility-Mobile Network Operations Control Center (MCFMNOCC) satellite communication systems. Scientists and test team members in the ExPOC could then discuss the sample data and the test activity's progress with the test subject and in-field team.

Several test objectives of the field test were addressed with the EVA traverse activities. Major objectives included:

1) Developing an EVA science infrastructure for planetary exploration,

2) Understanding and evolving the role of an Earth-based mission control center for exploration missions,

3) Studying human-robotic interaction by testing voice and gesture command methods, and

4) Generating the communication infrastructure requirements for long-distance EVA traverses.

The test subjects performed dry runs, and then each subject/suit performed one suited EVA geology traverse (see Table 2). 
The nighttime traverse was performed to assess the effectiveness of the secondgeneration, helmet-mounted LED light array. More powerful LEDs were utilized in the second-generation light array based on the feedback from the 2002 nighttime EVA LED light array trial. The test subject, wearing the Mark III suit, walked the oval traverse path, shown in Figure 8, which goes up an approximately 15 degree slope, over the crest of the hill, and down the backside of the hill. A full moon provided some ambient light (0.03 LUX) the night of the traverse. Light level measurements, as well as subjective comments during the traverse, were recorded. The ExPOC also participated in the night traverse.

Week 2 - EVA Traverse Results

General Traverse results-science trailer use comments

Limited information was collected regarding human-robotic interaction because the ERA experienced hardware and software problems. The ERA was used to pull the science trailer during one EVA geology traverse, however the ERA had to be controlled using a joystick.

Table 3: EVA Illumination Reference Data*

\begin{tabular}{|l|c|c|c|}
\hline \multicolumn{1}{|c|}{$\begin{array}{c}\text { Task Area } \\
\text { (From chest area) }\end{array}$} & Don/Doff Trailer & $\begin{array}{l}\text { Nighttime Traverse } \\
\text { Station \#2 }\end{array}$ & $\begin{array}{l}\text { Nighttime Traverse } \\
\text { Station \#4 }\end{array}$ \\
\hline $\begin{array}{l}\text { At } 0.457 \mathrm{~m}(18 \mathrm{in}) \\
\text { distance }\end{array}$ & $263 / 212 \mathrm{LUX}$ & N/A & N/A \\
\hline $\begin{array}{l}\text { Arms extended } \\
0.61 \mathrm{~m}(2 \mathrm{ft}) \text {--metric }\end{array}$ & 54 & N/A \\
\hline & & & \\
\hline $\begin{array}{l}\text { Ground Level Area } \\
\text { (from subject's } \\
\text { boots) }\end{array}$ & & & \\
\hline $0.91 \mathrm{~m}(3 \mathrm{ft})$ forward & $27.5 \mathrm{LUX}$ & $12.8 \mathrm{LUX}$ & $30 \mathrm{LUX}$ \\
\hline $1.83 \mathrm{~m}(6 \mathrm{ft})$ forward & 2.6 & 1.9 & 1.7 \\
\hline $2.44 \mathrm{~m}(8 \mathrm{ft})$ forward & 1.2 & 0.4 & 0.3 \\
\hline
\end{tabular}

* NOTE: Ambient light from full moon of 0.03 LUX

Details of the front of the Mark III were visible to observers at the donning stand at approximately 45.7 meters ( 150 feet) distance. The subject commented that the LEDs gave a natural color. He also noted that he would like to have some of the illumination focused farther forward for a greater visibility range.

The LAB experienced the same frozen vent/build-up valve problem as experienced on September $3^{\text {rd }}$, twice during Week 2 (before the nighttime EVA traverse on September $10^{\text {th }}$ and before the run the next day, September $\left.11^{\text {th }}\right)$. As before, the hot air gun was used to defrost the valve until it could be turned to build-up. After the field the test, the valve was removed, inspected, maintained, and replaced. No anomaly was observed during the 
inspection and the valve has functioned properly in LAB runs since then. It is suspected that moisture trapped in the valve was responsible for the problem.

Overall, the ExPOC was satisfied with their level of interaction during Desert RATS 2003. ExPOC personnel were able to view and participate in Week 2 EVA traverse activities. This was only the second year of ExPOC participation, and many lessons are being learned as these interactions mature. For example, during the 2002 field test, the primary objective was simply to create the link between the field and the ExPOC and to test its connectivity. Whereas, this year, scientists in the ExPOC were able to hear and see video, voice, and data transmitted from the field that allowed them to functionally participate in the test activities. (NEED TO COVER DEBRIEF COMMENTS FROM ExPOC)

General Test Results and Observations: Lessons Learned and Reemphasized With each subsequent field test, various lessons learned associated with the general process of getting to, conducting testing and simply being in the field are learned and relearned. As the test teams continue to grow the lessons are shared with newcomers and expanded upon. The following is a summarization of the most critical of these field test lessons learned.

\section{Lesson 1: Be prepared!}

-Performing dry runs at the JSC EVA Remote Field Demonstration Test Site (ERFDTS, a.k.a. 'Rock Pile') is of paramount importance for a successful field test. The need for dry runs cannot be over-emphasized. They should be performed early and often prior to a field test. Test systems that do not demonstrate readiness during the dry runs should not travel to the field test.

-Redundancies and spares are important. This lesson was reemphasized during the first week of testing when the $\mathrm{LAB}$ vent/build-up valve froze up the first time. There was only enough liquid air for one charge. Therefore, there was no air to top off the LAB charge to replace the air that was vented while the valve was being defrosted. The lesson was also driven home again on the drive back to Houston when three of the four Logistics trailer tires blew due to dry rot. The team only had one spare and an already-long driving day turned into a never-ending journey.

Lesson 2: Good communications are critical!

Poor communications hampered testing throughout the 2003 Desert RATS. Aside from increasing test team frustration levels, the experience painfully reinforced the previously learned lesson that good communications are critical. The following are suggestions for subsequent field tests to help insure good communications:

-When scouting a potential test site location, a site frequency survey must be included in the scouting team's data collection. The frequency survey results must weigh heavily in the field test site selection criteria.

-The communication system is a key component of the field test infrastructure. A 
suggestion for subsequent field tests is to plan for the test infrastructure teams, including the communication team, to be the first to arrive at the test site to set up and check out their systems before rest of team is ready to test.

-Communication system trouble-shooting takes a lot of valuable field test time. Avoid trouble-shooting in the field by performing integrated communications dry runs at the ERFDTS. Frequency management is an extremely consequential aspect of communication system performance. The difficulties experienced during this field test have also convinced the GRC and JSC Advanced EVA team to select a new suit voice communication system.

Lesson 3: Use field hardened equipment!

During Desert RATS 2003, several equipment failures further reinforced the importance of having field hardened equipment. Equipment designed for a controlled, laboratorytype environment invariably malfunctions when exposed to wind, dust, rain, bumps, and shakes. Further, field testing often pushes on the envelope of hardware performance limitations. Therefore, it is important to make sure you select equipment that can be operated well within its operating limits, even in the field test environment. Object lessons this year were:

-The van pulling the SCOUT team trailer broke down twice on the way to Flagstaff and eventually had to be replaced by a truck in Albuquerque.

- A chip in the ERA malfunctioned, and the ERA team had to drive to Phoenix to purchase a replacement. Although test time for human-robotic interactions was lost, EVA traverse testing continued using the 6WD ATV to pull the science trailer.

-The LAB vent/build-up experienced problems. The Advanced EVA team had no spares or work-arounds, and testing would have had to be aborted if the hot air gun had not been effective.

\section{Conclusion}

For information regarding other test participants' results, the authors can refer interested parties to the test reports produced by those Desert RATS teams.

\section{References}

Eppler, Dean B., 'Space Suit Test Subject Report, Meteor Crater Test Series, 1-12 September 2003' memorandum, September, 2003.

Kosmo, Joseph J., 'Remote Field Site Journal 8/30-9/14, 2003.'

Kosmo, Joseph J. and Amy J. Ross, 'Remote Field Site Space Suit Mobility Study Results', Society of Automotive Engineers $29^{\text {th }}$ International Conference on Environmental Systems Proceedings Paper Number 1999-01-1966, July 1999. 
Kosmo, Joseph J. and Amy J. Ross, 'Remote Field Site Space Suit Mobility Study Test Report Flagstaff, AZ May 2-17, 1998’, JSC 39096, June 1998.

Kosmo, Joseph, J. and Amy J. Ross, 'Results and Findings of the Representative Planetary Surface EVA Deployment Task Activities Remote Field Site Test Location Flagstaff, AZ (Sept. 2-15, 2000)', JSC 40106, October, 2000.

Kosmo, Joseph J., Robert C. Trevino, and Amy J. Ross, 'Results and Findings of the Astronaut-Rover (ASRO) Remote Field Site Test Silver Lake, CA (Mojave Desert) Feb. 22-25, 1999’, JSC 39261, March 1999.

Rochlis, Jennifer, 'Rover Ergonomics Study Results' notes, September, 2003.

Ross, Amy J., 'ExPOC Debrief with EC’ notes, October, 2003.

Ross, Amy J., 'Lunar Rover Vehicle Mock-up Advanced Space Suit Ingress/Egress Test Report', JSC 39922, May, 2000. 